http://dx.doi.org/10.12775/szhf.2014.045

ROOMET JAKAPI

\title{
Samuel Colliber on the Soul and Immortality
}

Samuel Colliber is an enigmatic figure in the history of British thought whose theory of the soul has received very little attention from historians of philosophy ${ }^{1}$. The current paper aims to contextualise and analyse the theory as presented in his Free Thoughts Concerning Souls. The work, accompanied by An Essay on Creation by the same author, was originally published in 1734 and reprinted with a short commentary by John W. Yolton in 1990. It is largely influenced by Locke's Essay but it also reflects the author's acquaintance with the views of such Early Modern philosophers as Descartes and some of the Cambridge Platonists.

Four essays constituting the work are entitled as follows: 1) "Of the humane soul consider'd in its own nature"; 2) "Of the humane soul compared with the souls of brutes"; 3) "Of the supposed præ-existent state of souls"; 4) "Of the future states of souls" (Free Thoughts Concerning Souls, p. I). In what follows, I will be concerned mainly with the content of essays 1 and 4 as these form a unified argument, whereas essays 2 and 3 will be discussed in passing since they are significantly shorter and could be seen as supplementary to the main line of thought.

\footnotetext{
${ }^{1}$ No biographical information is available about him. For an encyclopedic reference including bibliographical information, see J. W. Yolton, "Colliber, Samuel". An outline of his thoughts on the soul can be gained from Yolton's "Introduction" and Thinking Matter, pp. 42, 47. For an interpretation of Colliber's theology, see E. Scribano, "Samuel Colliber". His theology is also referred to in M. A. Stewart, "Arguments for the Existence of God", p. 716.
} 
Colliber's inquiry, which he calls "the anatomy of souls" (ibid., p. IV), is worthy of study for at least two reasons. First, his thoughts on souls modify Lockean and, in some contexts, Cartesian views and terminology in historically interesting ways resulting in a creative, though somewhat ambiguous, conception of his own. Second, the inquiry links an examination of the nature and operations of the soul in earthly life with an elaborate account of its states after death by means of diligent philosophical reasoning. The aim of this paper is to point out Colliber's views on the nature, operations and states of the soul in their philosophical and theological setting.

In the first section of the paper, I outline the philosophico-theological background and main features of Colliber's theory. The second section focuses on his metaphysical position on the nature of the soul. I argue that his position combines certain elements of substance dualism with the idea of substantial continuity between soul and body. In the third section, I present his description of the cognitive acts or operations of the soul against the background of Locke's Essay. Finally, the fourth section is concerned with Colliber's interpretation of the post-mortal states of souls. I will try to show how his characterisation of the afterlife fits into his overall theory.

\section{Background and overview}

Works of many well-known and less-known philosophers of the Early Modern period reveal how their specific conceptions of soul and body, in combination with specific religious beliefs, gave rise to different and sometimes fairly detailed accounts of the afterlife. Post-mortal states of the soul were normally seen and described in accordance with the theories describing the soul and its faculties in the present earthly condition. Thus, the theories dualist, materialist or idealist in nature - were carefully applied to the images of the separate existence of souls between bodily death and resurrection as well as their final state after the resurrection. These inventive combinations of Christian philosophy and theology could be seen as an epilogue or aftermath of a long Scholastic tradition.

Thomas Aquinas's thought - substantial in the development of the Roman Catholic doctrine of the soul - serves as an instructive background scheme for understanding the Early Modern accounts in question. In Aquinas's view, the human soul, taken as the form of the body, has nutritive, sensitive and intellective powers. While the nutritive and sensitive powers are exercised by means of bodily organs and thus pertain exclusively to the soul-body union, 
the activities of intellect and will, he thinks, "do not take place in bodily organs" (Summa Theologioe, Ia.77.5) and can be performed by the soul outside of its body as well (Summa Theologica. Supplement, 70.1). The human soul, while immaterial (Summa Theologioe, Ia.75.5), is not a substance in its own right, yet the intellective part of it can and will be separated from the body at death (Summa Theologica. Supplement, 70.1). The soul will stay in that incomplete condition until reunited with the body at the general resurrection. Separated souls are capable of ,imperfect and confused knowledge of natural things" (Summa Theologioe, Ia.89.3), intellectual vision (Summa Theologica. Supplement, 70.3) and abstract memory deriving from the intellective faculty (ibid., 70.2). They are also capable of suffering from corporeal fire adjusted as punishment for $\sin$ (ibid., 70.3). At the bodily resurrection, the sensitive powers will be restored and altered so as to make composite human beings suitable for everlasting life either in Heaven or Hell (ibid., 82.4; 86.1-3). The issues of personhood and individuation of disembodied souls are not clearly solved in Aquinas's theory and pose substantial difficulties for interpretation ${ }^{2}$.

Descartes famously argued in his Meditations that mind (or soul) and body are distinct substances whose essences - thought and extension - are fully known and exclusive of each other. As a proponent of new corpuscularian philosophy, he described the physical world in terms of mechanism and thus expelled the Aristotelian sensitive and nutritive souls from nature. As a Catholic, however, he was committed to the doctrines of immateriality and immortality of the human soul ${ }^{3}$. He construed the mind or soul as an indivisible, individual, immaterial thinking thing capable of separate existence. As his early critics pointed out, his proof of the "real distinction" between mind and body does not amount to a proof of immortality since the mind, although distinct from the body, may still cease to exist at the moment of bodily death ${ }^{4}$.

Descartes was careful to remain within the theoretical limits of his philosophical doctrine and typically did not delve into speculations on the exact condition of souls after death. Yet his theory does have implications for the understanding of the afterlife. His theory of the mind or soul includes the notion of pure intellect, that is, an autonomous immaterial faculty. Un-

\footnotetext{
${ }^{2}$ For discussion see e.g. E. Stump, Aquinas, pp. 52-54, 211, 517-518, S. Goetz and Ch. Taliaferro, A Brief History of the Soul, pp. 55-61.

${ }^{3}$ See C. F. Fowler, Descartes on the Human Soul.

${ }^{4}$ For the objections and replies, see R. Descartes, Philosophical Writings, II, pp. 91, 108-109, $143-144,161$.
} 
like the workings of the senses, memory and imagination, he suggested, pure intellection takes place independently of the body (Philosophical Writings, II, pp. 51, 248). In his view, it would seem that immortal disembodied souls, even though deprived of their other cognitive powers, would retain this autonomous faculty ${ }^{5}$. Moreover, in some contexts he introduced the notion of a purely intellectual memory, that is, an additional mental power that works independently of the body ${ }^{6}$. In a letter to Huygens from 10 October 1642 he attributes that power to separated souls (Philosophical Writings, III, p. 216). Despite their divergent theories of soul and body, Descartes' views on the cognitive capacities of disembodied souls were not so very different from Aquinas's.

Protestant philosophers in the seventeenth and early eighteenth century England explored various possibilities in the interpretation of the afterlife. While generally rejecting the Catholic belief in Purgatory, they either did or did not embrace the doctrines of natural immortality and the separate state of souls. Hobbes, for instance, did not. He was a materialist and mortalist who denied the existence of immaterial souls and, consequently, the possibility of their disembodied existence between bodily death and resurrection (see Leviathan, chs. 34, 38).

Quite a few Protestant thinkers who adopted the doctrines of immortality and separate state of the soul described that state in light of their philosophical principles. The Cambridge Platonist Henry More, for example, offered a comprehensive account of the post-mortal life of souls in the framework of his overall theory of different kinds of spirits and bodies. On his view, souls, while separated from their earthly bodies, inhabit aerial bodily vehicles and, by means of these, exercise their cognitive faculties to a full extent (The Immortality of the Soul, pp. 210-215). In fact, More thought that, in that state, the "perceptive faculties" of the soul will be "more quick and perfect" than in the present life (ibid., p. 196). Eventually the souls of the saved obtain aethereal vehicles that enable them to survive the conflagration of the world (ibid., p. 302). In contrast to Descartes, More held that all substances

\footnotetext{
${ }^{5}$ See D. Garber, "Soul and mind", p. 767.

${ }^{6}$ For discussion and references, see G. Hatfield „The cognitive faculties“, p. 969; U. Thiel, "Personal identity", p. 883; D. Clarke, Descartes's Theory of Mind, pp. 99-105; K. J. S. Forstrom, John Locke and Personal Identity, p. 45; U. Thiel, The Early Modern Subject, p. 82.
} 
(including matter, human souls and God) are extended, but he distinguished between material and spiritual extension (ibid., pp. 28-30) ${ }^{7}$.

Locke argued in his Essay that the notion of immaterial substance or soul is not necessary to account for personal identity and immortality. Instead, he focused on the notion of continuous consciousness extending from earthly life and deeds to the reception of final rewards or punishments after bodily resurrection and the Last Judgement (II.XXVII.15, 18-22, 26). He neither denied nor approved explicitly the existence of immaterial souls. His wellknown official view on the nature and basis of thinking is agnostic: "we know not wherein thinking consists, nor to what sort of substances the Almighty has been pleased to give that power" (ibid., IV.III.6). God may have superadded to certain systems of matter either a faculty of thinking or, alternatively, an immaterial substance having that faculty (ibid.; cf. II.XXIII.30-32). Whether or not Locke (unofficially) inclined to materialism and mortalism is a matter of debate ${ }^{8}$.

Like Descartes and unlike Locke, Colliber argues for the distinctness and separability of soul and body. However, he does not think that the soul is a purely immaterial being whose essence excludes everything corporeal. He uses and changes Locke's vocabulary and concepts to describe the powers and operations of the soul, considering all cognitive operations as modes of perception or sensation. Colliber's strategy is to show that these operations proceed from a single cognitive faculty that is inseparable from the soul and can be exercised outside of the body as well. Furthermore, he states that some operations of the soul (most notably internal sensation) work independently of the body, both in this life and the next. On the whole, Colliber's vision of the afterlife is carefully constructed on the basis of his general examination of the soul and its powers. As a "true protestant", he discards the doctrine of Purgatory, but embraces the doctrine of the separate or intermediate state (Free Thoughts Concerning Souls, pp. III, 105). He does not offer an account of the individuation of souls or of personal identity over time.

\footnotetext{
${ }^{7}$ See also J. Reid, "Henry More on material and spiritual extension" and The Metaphysics of Henry More.

${ }^{8}$ For discussion, see A. W. Wainwright, "Introduction“, pp. 53-54; N. Jolley, Locke. His Philosophical Thought, pp. 100-101; V. Nuovo, "Locke’s theology", pp. 192-194; J. Marshall, "Locke, Socinianism, 'Socinianism', and Unitarianism“, pp. 147-150, 159-160; J. W. Yolton, The Two Intellectual Worlds of John Locke, p. 131; B. W. Ball, The Soul Sleepers; L. P. Dempsey, "A compound wholly mortal“; U. Thiel, The Early Modern Subject, p. 133.
} 


\section{Nature of the soul}

Colliber begins his inquiry with an outline of what he takes to be Aristotle's conception of the "three distinct souls in man": vegetative, sensitive and rational (Free Thoughts Concerning Souls, p. 1). As an adherent of corpuscularian natural philosophy, he rejects the distinction, claiming that the vegetative principle in us is to be understood in terms of certain refined particles of the body, or vital spirits, "which carry on the circulation of the blood, on which the life and growth of our bodies immediately depend, as do the life and growth of plants on the motion of the sap" (ibid., p. 2). He further argues that the distinction between the sensitive and rational soul has no foundation since "we are conscious but of one perceptive principle within us" (ibid.). The single "perceptive principle", "thinking principle" or "thinking perceptive principle" accounts both for reasoning and sense perception, so "tis unreasonable to suppose more than one" (ibid., p. 5). The principle thus uncovered is no other than the human soul (ibid.).

Colliber defines "thinking or thought (in a large sense)" as "any internal act, of which we are immediately conscious, with regard to objects". Thinking, taken in the general sense, has two principal modes: "sensation or perception (which is thinking in the strict sense)", and "volition or willing", each being "capable of its particular modes and differences" (ibid., p. 3). These formulations follow corresponding statements in Locke's Essay but the wording is somewhat altered. Locke also speaks of thinking in a broader and narrower sense and makes a distinction between the "two great and principal actions of the mind [...]: perception, or thinking, and volition, or willing" (Essay, II.VI.2; cf. II.I.1;). For him, "sensation" is a term confined to sense perception (ibid., II.I.3-4), whereas for Colliber it covers a much wider spectrum of cognitive acts or modes of thinking (see sect. 3 below).

Colliber's account emphasises the soul's activity in perception. He seems to consider attention to be an action of the soul that is at least minimally present in all forms and instances of "sensation or perception". (Free Thoughts Concerning Souls, pp. 3-4, 91). Locke, by contrast, does not ascribe such an extensive role to attention. In the reception of simple ideas, he says, the mind is "wholly passive" (Essay, II.XII.1; II.XXII.2)9.

\footnotetext{
${ }^{9}$ For a recent analysis of activity in perception according to Locke, see V. Lähteenmäki, "Locke and Active Perception".
} 
In place of the Aristotelian three kinds of souls, Colliber introduces three principal "faculties or powers" of the single unitary soul: sensitive or perceptive, volitive and executive (Free Thoughts Concerning Souls, pp. 2, 4). In his view, a single faculty or power is responsible for all our cognitive acts or operations, namely external sensation, internal sensation, memory, imagination, intuition and reasoning (ibid., pp. 3-5).

The volitive power or faculty is responsible for volition described as an "internal motive to action" (ibid., 50) known to us via consciousness and also manifested "in our equal ability of choosing any one of two or more objects of apparently equal value" (ibid., p. 51). This "self-motive power" renders the soul distinct from matter since the parts or portions of matter are "moved necessarily, according to fix'd laws" (ibid., pp. 52-53).

Finally, the executive faculty is concerned with the immediate production of external action when we move our bodies. The executive power depends on - but is different from - the volitive. He illustrates the distinction between these two powers by saying that the notions we have of them "are as different as those of commanding and obeying" (ibid., p. 4). Not much can be said about the executive power, though, since we lack a positive idea of its "manner of acting" (ibid., p. 53).

Colliber's list of the cognitive operations is derived from Locke, but it is shorter, closed and adjusted to his conception of a unitary cognitive faculty ${ }^{10}$. While "imagination" does not occur in Locke's catalogues of the operations of the mind and modes of thinking (Essay, II.VI.2; II.IX-XI; II.XIX.1-2), Colliber uses the word to signify the abstracting and compounding of ideas. The distinction between three faculties does not stem from Locke, for he distinguishes between two principal powers of the mind - understanding and will - that "are denominated faculties" (Essay, II.VI.2; cf. II.XXI.5-6). Locke does not introduce a specific mental power in addition to the will to explain how we move our bodies.

Relying on this preliminary description of thinking and the faculties, Colliber argues for the "essential distinctness" and separability of soul and body. He provides a detailed discussion and criticism of the materialist claims that the soul is either "a single indivisible particle (or atom)" in the brain or "a composition, or, at least, the result of a composition of such particles" (Free

\footnotetext{
${ }^{10}$ The reduction of cognitive operations to the workings of a single faculty is perhaps more reminiscent of Descartes's view that "sensory perception, imagination and pure understanding are simply various modes of perception“. Philosophical Writings, I, p. 204; cf. ibid., p. 42.
} 
Thoughts Concerning Souls, p. 15 ${ }^{11}$. If these identity claims fail, he holds, the soul must be a simple unitary thinking thing distinct and separable from the body (ibid., pp. 5-6, 21-2). He focuses on sense perception, aiming to introduce the unitary soul as the only possible explanation for the number, variety, coherence and connectedness of our sensations.

If the soul is to be identified with some part or particle of the body, Colliber says, it must reside in the animal spirits of the brain, for the latter are certainly concerned with thinking (ibid., pp. 8-9). He first considers the possibility of identifying the soul with a single particle in the brain. One particle, he says, cannot receive at once such a variety of sensations as the soul receives. The particle would receive sensations by means of impressions from other particles in the brain (ibid., p. 10). If the particles are of equal size, then a single particle cannot receive "more than one full sensible impression on a side at once", but a single impression "made by a single particle" cannot "excite any variety of sensations" in another particle (ibid., p. 13). There are no grounds to suppose that the particles of bodies are of unequal size, however (ibid., pp. 11-12).

He then proceeds to assess the view that the soul is either a composition, or a result of a composition, of particles in the brain (ibid., p. 15). The soul must be something fixed, he says, "otherwise our thoughts would be in a continual fluctuation and confusion", and we couldn't pursue "any one design". The animal spirits, on the contrary, are "volatile and in a perpetual motion" (ibid.). Furthermore, the soul must be one thing, not many, "otherwise our sensations would be broken and incoherent, and our consequent actions less consistent and uniform" (ibid., p. 16). Hence the soul cannot be identified with a composition of particles.

Colliber posits that the motion of animal spirits can excite sensations of colour, sound and pain only in a being that is endowed with "thinking powers". A composition of moving particles of a certain size and figure cannot produce these powers since the particles as such do not have them nor anything equivalent to them (ibid., pp. 16-19). Composition does not change the nature of things composed (ibid., p. 18). Hence thinking cannot result from a composition of particles.

${ }^{11}$ The discussion seems to be inspired by Locke's examination and refutation of the materialist ideas that the eternal thinking being responsible for our existence could be identified either with "one atom" or "a composition of particles of matter". Essay, IV.X.15-16. 
Finally, if we do think of the particles as being to some degree sensitive or conscious, this would not allow for a perception of whole objects. Each particle would perceive a part of the object, but nothing could bring about a unified sensation of it (ibid., pp. 19-20).

On these grounds, Colliber concludes that the soul is not a part of the body, nor "resulting from or essentially depending on it", and therefore "it is a being essentially distinct" (ibid., p. 21). From the distinctness of soul and body necessarily follows their separability (ibid., p. 24) and, in the final analysis, natural immortality of the soul (see sect. 4 below).

Interestingly enough, his refutation of the materialist claims in question does not presuppose or entail the Cartesian idea of the soul as a wholly immaterial substance. On the contrary, while maintaining that the soul is "essentially distinct" from matter, Colliber also says that it is "of a substance not wholly" or "totally different from matter, because it is passive as well as active" (Free Thoughts Concerning Souls, pp. 22-23) ${ }^{12}$. At this point he quotes Locke: "pure spirit, viz. God, is only active, pure matter is only passive; those beings that are both active and passive, we may judge to partake of both" (ibid., p. 23; cf. Locke, Essay, II.XXIII.28). He disagrees with philosophers who refine the soul from everything corporeal and define it in terms of pure activity. In other words, for him, the soul shares the property of passivity with the body and the property of activity with God. Note, furthermore, that his position does not exclude the possibility that soul and body have additional features in common, not only passivity ${ }^{13}$.

Colliber provides further support for the view that the soul is different and separable from the body by offering a whole list of actions that the former can perform independently of the latter, "or, at least, above the capacity of its bodily sensories and members" (Free Thoughts Concerning Souls, p. 31). The list includes the soul's abilities to have a conception of God, form general ideas from individual ones, determine itself to action, reflect on itself and its actions, correct mistakes of the senses and imagination, use one sense instead

${ }^{12}$ He holds that in addition to its acts or thoughts, the soul contains "affections or passions" such as joy, fear, hope and grief "which naturally follow sensations". Free Thoughts Concerning Souls, pp. 27-28.

${ }^{13}$ In an appendix to his earlier work An Impartial Enquiry, Colliber suggests (in opposition to Cartesians) that extension is such a feature or property. Cogitation, he says, presupposes "some sort of extension or expansion as its immediate subject". An Impartial Enquiry, p. 267. The human mind could not receive ideas of extended things "if its own nature admits of nothing like extension“. Ibid., pp. 267-268. 
of another (as in the case of using letters for spoken words), invent devices far more powerful than the human body, act on the animal spirits with a force that exceeds the strength of the body (ibid., pp. 31-35). These abilities surpass the powers and workings of bodily organs, thus indicating that the soul is an autonomous subject capable of perceiving, willing and acting in the absence of its body.

To sum up, Colliber construes the soul as a unity - a stable and indivisible thinking thing - and matter as a plurality of moving particles. He holds that matter cannot think or produce thinking. However, he does not say that thinking constitutes the very essence of the soul and that no additional properties (in common with matter) could belong to it. The natures of soul and body are different but not completely disparate, for passivity belongs to both. His metaphysical stance is not explicit. Since he does not take the soul to be an immaterial substance entirely distinct from matter, he cannot be called a Cartesian substance dualist. At the same time, he believes that human soul and body are full-fledged entities - things capable of separate existence which precludes attributing property dualism or materialism to him. It could be said that he tries to combine certain elements of substance dualism (the concept of a simple, unitary thinking thing, distinctness and separability of soul and body) with the idea of substantial continuity between soul and body (with passivity as a shared essential feature).

\section{Modes of sensation}

Colliber describes the cognitive acts or operations of the soul by means of Lockean terms and conceptions modifying these with his own interests. In general, he remains faithful to Locke's empiricism, but he talks about all cognitive operations in terms of modes of "sensation or perception". While Locke starts the presentation of his positive theory by introducing two sources of ideas - sensation and reflection - Colliber begins his account of the cognitive acts by introducing a distinction between two kinds of sensation: simple (single) and comparative (compound) (Free Thoughts Concerning Souls, pp. 3-4). Simple sensation is either internal or external. In both ways of simple sensation the soul is active insofar as it attends "either to a single impression or idea" (ibid., p. 3).

His use of the terms "idea", "impression" and "sensation" needs a little clarification. While he does not explain the exact meaning of these words, he seems to hold that idea is a representational item present in the soul in all 
forms of perception (ibid., pp. 3-4, 37). Ideas are of various things, they represent internal objects or operations of the soul (ibid., pp. 37-38), as well as external objects (ibid., pp. 38, 41-42, 81). Ideas are individual or made general "by abstracting, or compounding" (ibid., pp. 60, 31). Examples of more abstract or general ideas are those of existence, happiness and unhappiness (ibid., p. 85). No mention is made of innate ideas. Impressions, in the primary meaning of the word, are physical items to be found in sense organs. They are caused by and represent external objects (ibid., p. 40). While introducing the concept of internal sensation, however, Colliber indicates that the soul can also acquire impressions of its internal operations. In this context, he seems to consider impressions as mental items (ibid., p. 3). The term "sensation" is used by him in three ways: either in a general meaning, synonymously with "perception"; in conjunction with the words "internal", "external", "intuitive" and "rational" and therefore signifying particular modes of thinking; or, finally, as a name for a particular act of sense perception. His vocabulary also includes the term "notion" that could be taken in the sense of "concept", "conception" or "apprehension". Notions are of "things and actions" (See ibid., pp. 3, 39, 42, 104).

Colliber's account proceeds as follows: Through internal sensation we perceive "our own existence" and internal actions and passions "which perception renders us, as it were, the objects of our own thought, by a sort of reflection" (ibid., p. 3). By reflecting on its "properties and operations", the soul receives ideas of its own "powers and acts of perceiving and willing" (ibid., pp. 37-38). He does not specify the content of these ideas any further, but he contends that they "are very different from the ideas excited by the external sensories" (ibid., p. 38).

The concept of internal sensation is acquired from Locke for whom "internal sense" is another name for reflection (Essay II.I.4). However, there are some noticeable differences between the two thinkers' views on this mental activity. Firstly, Locke does not say that the awareness of one's own existence is given through internal sense, for he thinks that it is given via intuition (Essay IV.IX.3) ${ }^{14}$. Secondly, Colliber introduces a minor conceptual distinction between reflection and internal sensation: "The act of attention, being, as it were inverted, produces reflection; from whence results the internal sensation" (Free Thoughts Concerning Souls, p. 37). So he takes reflection to be an

\footnotetext{
${ }^{14}$ For a recent analysis of Locke's understanding of the awareness of the self, see U. Thiel, The Early Modern Subject, pp. 118-120.
} 
activity that leads to the perception of internal objects rather than the perception itself. Finally, he holds that the soul reflects on itself and also remembers ideas received by reflection independently of the body (ibid., pp. 32, 39). Internal sensation, along with the relevant branch of memory, is peerless among our cognitive activities since the work of the rest of these activities hinges on bodily organs to some extent. Locke, by contrast, does not claim that reflection is unrelated to physical processes in the body, for his account of this source of ideas is neutral as to the basis of thinking, be it immaterial or material.

It could be said that the status of internal sensation in Colliber's thought is somewhat similar to that of pure intellection in Descartes' philosophy. In both cases, we are dealing with an autonomous mental operation that is contrasted with other modes of thinking on the basis of its complete independence of the body. Colliber himself does not speak of pure intellect or pure intellection at all except in the metaphorical sense of contemplating God and other superior beauties with "the intellectual eye" (ibid., p. 34).

Unlike internal sensation, external sensation is conditioned by a chain of physical motions extending from external objects that make impressions on our sense organs to appropriate motions of animal spirits in the brain. In other words, the soul, seated in the brain, has sensations and ideas of external objects due to its connection to the body (See ibid., pp. 8-9, 25-26, 40-41). However, sensations themselves are not corporeal; they "are pure thoughts of the soul" (ibid., p. 17). Most members of the bodily apparatus - even the "grosser substance" of the brain - are not strictly necessary to produce sensations. The soul could have ordinary sensations of external objects if merely the animal spirits were present, "wrought upon" by the objects and affecting the soul "in the usual manner" (ibid., p. 87). As we shall see, Colliber uses this idea to account for external sensation in the separate state of souls.

Memory and imagination rely on external and internal sensation, according to Colliber, and are also particular branches of sensation. More precisely, memory is "the sensitive faculty as concerned either in retaining or reviving the sensations and ideas or notions of things" (ibid., p. 39), whereas imagination is "the sensitive faculty as concerned either in abstracting or compounding ideas" (ibid., p. 42; cf. Locke, Essay, II.X; II.XI.6,9-12; II.XII). Unlike Locke, Colliber focuses on the relationship these operations have with the body. The acts of memory and imagination regarding external objects "proceed purely from the different sorts and degrees of motion in the spirits of the brain" (ibid., p. 38). The fact that particular memories of external 
objects can be completely lost or badly damaged by virtue of a brain injury shows that ideas of those objects "are not fix'd in the soul" and, consequently, the memory of those objects is confined to the present, embodied state (ibid., p. 42). On the other hand, remembrance of the ideas of reflection is independent of the body, as explained above. He also implies that the workings of imagination are not completely determined by the brain since the soul can, to some extent, freely separate or unite ideas by exercising "a power inherent in itself" (ibid., pp. 42-43).

Comparative sensation is defined as "the perception of the agreement or disagreement of divers ideas, arising from comparison" (ibid., p. 4). There are two kinds of comparative sensation - intuitive and rational - and two kinds of comparison - immediate and intermediate. Intuitive sensation (or intuition) "is our attention to the agreement or disagreement of two ideas", rational sensation (or reasoning) "is our attention to the agreement or disagreement of three or more" ideas (ibid.). Intuition "produces" self-evident knowledge on which reasoning is "built" (ibid., pp. 47-48). Colliber regards reasoning as a mode of sensation, but he nonetheless explains it as the combined work of the volitive and sensitive faculties (ibid., p. 45). The notion of reasoning comprises several "acts of attention", namely sagacity, judgement and understanding (ibid., p. 46). While reason is not a distinct faculty, it is independent of imagination and superior to it (ibid., pp. 48-49). Since the capacity of reasoning does not vanish completely "on occasion of blows or wounds in the head", Colliber believes, it is "not absolutely dependent on the matter or structure" of the body (ibid., p. 50).

Colliber's notions of intuitive and rational sensation are creatively derived from Locke's conceptions of knowledge and reason. Locke distinguishes between and gives an elaborate account of three degrees of knowledge (intuitive, demonstrative or rational, and sensitive) (Essay, IV.II.1-2,14; IV.XVII.14-17). $\mathrm{He}$ analyses the workings of reason in a detailed manner aiming to explain how exactly we can attain certain knowledge in cases where it is not attainable by an immediate comparison of two ideas. Colliber's aim is not to develop a theory of knowledge. He wants to provide a comprehensive list and general characterisation of the cognitive acts understood as modes of sensation. It seems that he emphasises the unity of and continuity between all cognitive activities in order to show that the perceptive faculty as a whole is inseparable from the soul and can be exercised outside of the body as well. The various modes of "thinking in the strict sense" depend on the body to a different extent, but none of them will be completely lost in the separate state. 
Colliber's account of the cognitive acts or operations can be summarised as follows. All of these operations are understood as modes of "sensation or perception" proceeding from a single faculty. Some of them (external sensation, and imagination and memory regarding external objects) are realised by virtue of underlying physical processes. Others (like reasoning) are to some extent independent from physical motions in the brain. Finally, internal sensation, along with the relevant branch of memory, is an activity of the soul that does not depend on the body at all.

\section{The future states}

Colliber determines that by showing the distinctness and separability of soul and body, the natural immortality of the soul is proven too - at least in conjunction with the three arguments he later gives in reply to the objection that souls might be annihilated in bodily death. Souls will survive death and preserve their faculties because, firstly, humans have a natural desire for and hope of "perpetual existence, in possession of their natural faculties"; secondly, and most importantly, conscious afterlife is necessary for the distribution of divine justice; and finally, even the particles of matter remain in existence after the dissolution of bodies to which they belong, so there is hardly any reason to suppose that souls (the more noble beings) will be annihilated (Free Thoughts Concerning Souls, pp. 55-56) ${ }^{15}$.

He proceeds to examine the abilities and activities of the soul in the postmortal separate state, maintaining that "the soul must remain entire even after the death of its body, and must still retain the powers and properties which it before possess'd independently of the body" (ibid., p. 25). He thinks that all three faculties of the soul are preserved and can be exercised, at least partly, in the absence of body (ibid., p. 28). He repudiates the view adopted by some Christian Platonists (such as Henry More) that separated souls inhabit aerial vehicles that enable them to perform their actions. The view, he argues,

\footnotetext{
${ }^{15}$ Colliber argues that natural immortality applies to "the souls of brutes", as well. In the second essay of his book, he attributes to animal souls a number of cognitive operations, namely external sensation, imagination, memory and intuition. Free Thoughts Concerning Souls, pp. 57-77. He holds that animal souls are substances and therefore they will probably survive bodily death by passing from one mortal body to another until God unites them with immortal ones. Ibid., pp. 94-97.
} 
is of heathen origin and has nothing to do with Christian revelation (ibid., p. 102$)^{16}$.

As the soul in its present state perceives external objects by the mediation of a bodily apparatus, sensations are caused in a roundabout way and therefore are "proportionably more languid and faint" (ibid., p. 26). In the disembodied state after bodily death, however, sensations of external objects will be not only more lively but also more accurate:

as the soul, in a separate state, will probably have, other sensations to which it is now a perfect stranger, so 'tis reasonable to think its sensations will be not only more lively, but more true, or more agreeable to the natures of things. At present, no other sensations are excited in our souls by the means of external objects, but such as our sensories are fitted to excite. Things appear not to us naked as they are in themselves, but cloath'd with qualities foreign to their natures. What at present excites the sensation of red, or yellow, or any other colour, will when we have a true sensation, appear to be a very different thing: As is clear from the very different appearances of bodies when view'd through a microscope.

(Ibid., pp. 26-27.)

Thus our present bodily constitution is an impediment on the soul's true perception of the external world. Objects appear to have colours and some other qualities that do not belong to their nature and therefore vanish as soon as we have an opportunity to look closely enough. The separation of soul and body at death removes this impediment so that sensations in the disembodied soul are "more immediately" excited by the objects (ibid., p. 27). How exactly this "more immediate" production of sensations works, is not so clear, but Colliber suggests that some kind of physical mediator between the external object and the soul is needed even in that situation:

if the grosser substance even of the brain itself were dissolv'd, yet if the spirits, or any other subtile particles, were still capable of being wrought upon by objects and of affecting the soul as usual, the soul tho' separate from the body, might, by their means, be capable of its usual sensations.

(Ibid., pp. 87-88, emphasis added.)

\footnotetext{
${ }^{16}$ In the third essay of his book, he likewise dismisses the position of the Platonists according to which souls are all created at once and inhabit aerial vehicles before their descent into terrestrial bodies. Free Thoughts Concerning Souls, pp. 78-85.
} 
Bodies cannot affect the soul directly. The animal spirits (or other subtile particles) serve "as the immediate instruments of the soul's sensations of external objects"; their motions are necessary for the production of those acts (ibid., p. 16) ${ }^{17}$. So, strictly speaking, the disembodiment is not complete since the soul still uses some kind of corporeal instruments. At any rate, Colliber believes that in the separate state we have genuine sensations of external objects, followed by the same or similar kind of affections and passions as we experience in this life (ibid., pp. 27-28).

Colliber does not explicate what he means by the "natures" of bodies, but his discussion of the matter appears to be related to Locke's notion of real essences. By the "real essence" of a body Locke means its "internal constitution" (Essay, III.VI.9) or "the constitution of the insensible parts of that body" (ibid., III. VI.2). He thinks that due to the limitations of our present faculties and bodily organs, the real essences are and remain unknown to us and we cannot perceive them. Colliber agrees with Locke that because of the extreme minuteness of particles, the real nature or constitution of bodies cannot be discovered even by means of microscopes (Free Thoughts Concerning Souls, pp. 29-30; cf. Locke, Essay, II.XXIII.11-12). Both thinkers believe, however, that the internal constitution of bodies is more accessible to created beings (besides the supreme uncreated being) who are not bound by the constraints of ordinary human bodies. As we saw, Colliber thinks that disembodied souls have a more adequate perception of the external world than we have at present. He also suggests that angels may possibly have a closer perception of the physical world since they have bodies that are "more refined than the human body" and "serve as instruments not only of external sensation but of memory; as well at least or much better than our grosser bodies" (Free Thoughts Concerning Souls, pp. 92-93). Locke's position on the possibility of disembodiment of souls is not evident, but he does find it possible that angels have a better knowledge of the constitution of bodies than we have in this life (Essay, III.VI.3). Angels, whether embodied or not, "may probably have" cognitive capacities that exceed ours and are inconceivable to us (see ibid., II.X.9; II.XXIII.13; IV.XVII.14).

Moreover, Colliber believes that the separated soul can exercise its executive power and move bodies (Free Thoughts Concerning Souls, pp. 28-29).

${ }^{17}$ Henry More argues for the same kind of view except that he thinks that separated souls inhabit aerial vehicles. Animal spirits are instruments "whereby the soul immediately exercises the functions of sense" both in this life and the next. The Immortality of the Soul, p. 178; cf. ibid., p. 195. 
How precisely this would happen is left unexplained. As he admits, the operation of the executive power is somewhat mysterious by itself; still more mysterious is its activity when the soul is detached from its ordinary bodily instruments ${ }^{18}$.

What is clear, according to Colliber, is that disembodied souls can perform most of their cognitive and volitive operations ${ }^{19}$. The "only imperfection of souls in the unbodied state", he says, is "the want of a particular remembrance of external objects" (ibid., pp. 103-104). They cannot retain or revive sensations of those objects since these acts of memory depend "entirely on a body" (ibid., p. 42, cf. pp. 38, 90-92). However, the souls will have "general notions of things and actions" and "a general notion of their past conduct while embodied“. They will be conscious of "their good or bad conduct in the present state", and feel happiness or unhappiness, respectively (ibid., p. 104). Moreover, separated souls will be employed with "speculation" - contemplation of the nature of intellectual objects such as God, the souls themselves, and probably "innumerable species of beings invisible to us" (ibid., p. 105). Presumably, these objects would be perceived by means of „the intellectual eye" mentioned earlier.

All in all, it follows that both external and internal sensation can be fully exercised in the intermediate state, but only internal objects can be remembered. Memory of one's earthly life and deeds is present, but it lacks detail. Imagination, intuition and reasoning are not specifically discussed in this context, but we are led to conclude that these operations can be performed to the extent they are independent of the body.

As for the final state, Colliber first considers the nature of resurrection bodies and then proceeds to discuss the psychological consequences of the reunification of souls and bodies. Resurrection bodies, he says, "will consist of the same individual substance" as the former earthly bodies, but they will be "refined, and in all respects so disposed as to be more capable of assisting the soul's operations" (ibid., p. 115). Thus, he does not think that the composition of particles constituting the earthly body needs to be restored at resurrection. By means of the refined or spiritual body, "the remembrance of the minutest actions and circumstances of actions will be revived" to make souls

\footnotetext{
${ }^{18}$ By way of comparison, Henry More's theory of bodily vehicles enables him to say that souls, in the separate state, can voluntarily direct the moving particles of their aerial bodies. The Immortality of the Soul, p. 195.

${ }^{19}$ The metaphysical positions of Descartes and Aquinas would not allow for such a wide scope of operations to be performed by separated souls (see sect. 1 above).
} 
suitable for the Final Judgement (ibid., p. 116). That is to say, due to the fine though unknown constitution of the resurrected body, memory will function perfectly, comprising innumerable details concerning our earthly lives. Colliber does not specifically discuss differences between the bodies of the saved and those of the damned, but he assumes that these bodies will be such that they enable the souls to inhabit Heaven and Hell, respectively. Both the happiness of the saved (consisting of intellectual pleasures) and the misery of the damned will be eternal (ibid., pp. 126-127, 130). The intensity and extent of sensations in Heaven is described as follows:

as both our external and internal sensations have been observ'd to proceed from one and the same perceptive faculty, 'tis not unreasonable to think that the perceptive faculty, in it's full latitude, will be gratified in every suitable manner, even to the utmost extent of our present regular wishes and desires. And not only so, but that it will, as we before observ'd, be gratified with other sensations which, at present, we know nothing of.

(Ibid., p. 128.)

The knowledge of divine things as well as the intellectual pleasures will probably increase by degrees since all of it would be too much to receive at once (ibid., pp. 129-130).

On the whole, Colliber's fairly detailed account of the acts of the soul in its post-mortal states is derived from his general theory of the soul preserving the same psychological concepts and distinctions. In the separate state, the soul will be able to exercise all of its three faculties, although the lack of body will put specific limits on its operations. Furthermore, the disembodied soul will have sensations of external things that present their nature more adequately than ordinary sensations do. The perceptive, volitive and executive capacities of the soul will be fully realised in the final state.

\section{Conclusion}

Colliber's thoughts on the nature, faculties and operations of the human soul rely heavily on Locke's views put forward in his Essay. However, we have seen that he often modifies Locke's terminology, formulations and positions for the sake of his own agenda. Colliber wants to show that the soul is distinct and separable from the body and can exercise its powers not only in this life, but also in its disembodied existence after death as well as after the bodily resurrection. He subsumes all cognitive capacities under a single faculty of sen- 
sation or perception and claims that some operations of the soul (especially internal sensation) are performed independently of the body. He argues that souls, while separated from their earthly bodies, retain their faculties and explains in a fairly detailed way what operations they can perform in that condition. At the same time, he does not believe that the soul is wholly immaterial, but rather that the soul as an active and passive being participates in God as well as matter.

\section{Acknowledgements}

This work was supported by the Estonian Science Foundation under Grant 8715 . The author would like to thank Toomas Lott and Bruno Mölder for comments on earlier versions of the paper, and Rachel Kinbar for linguistic revision of the final version.

\section{Bibliography}

Aquinas, St. Thomas. Summa Theologica. Supplement. In St. Thomas Aquinas, Summa Theologica. Vol. 5. Translated by Fathers of the English Dominican Province. Christian Classics, 1981.

Aquinas, St. Thomas. Summa Theologice. Latin text and English translation, introduction, notes, appendices \& glossary. Vol. 11: Ia. 75-83. Edited by Timothy Suttor. Cambridge: Cambridge University Press, 2006.

Aquinas, St. Thomas. Summa Theologice. Latin text and English translation, introduction, notes, appendices \& glossary. Vol. 12: Ia. 84-89. Edited by Paul T. Durbin. Cambridge: Cambridge University Press, 2006.

Ball, Bryan W. The Soul Sleepers: Christian Mortalism from Wycliffe to Priestley. Cambridge: James Clarke, 2008.

Clarke, Desmond M. Descartes's Theory of Mind. Oxford: Clarendon Press, 2003.

Colliber, Samuel. An Impartial Enquiry Into the Existence and Nature of God: Being A Modest Essay Towards a More Intelligible Account of the Divine Perfections. The Third Edition. London: Robinson, 1735 [1718].

Colliber, Samuel. Free Thoughts Concerning Souls. In Four Essays. Bristol: Thoemmes, 1990 [1734].

Dempsey, Liam P. "A Compound Wholly Mortal": Locke and Newton on the Metaphysics of (Personal) Immortality". British Journal for the History of Philosophy 19, no. 2 (2011), pp. 241-164.

Descartes, René. The Philosophical Writings of Descartes. 2 vols. Translated by John Cottingham, Robert Stoothoff, and Dugald Murdoch. Cambridge: Cambridge University Press, 1985. 
Descartes, René. The Philosophical Writings of Descartes. Vol. 3: The Correspondence. Translated by John Cottingham, Robert Stoothoff, Dugald Murdoch, and Anthony Kenny. Cambridge: Cambridge University Press, 1991.

Fowler, C. F. Descartes on the Human Soul. Philosophy and the Demands of Christian Doctrine. Dordrecht: Kluwer Academic Publishers, 1999.

Forstrom, K. Joanna S. John Locke and Personal Identity. Immortality and Bodily Resurrection in 17th-Century Philosophy. Continuum, 2010.

Garber, Daniel. "Soul and Mind: Life and Thought in the Seventeenth Century". In The Cambridge History of Seventeenth-Century Philosophy, edited by Daniel Garber and Michael Ayers, pp. 759-795. Cambridge: Cambridge University Press, 1998.

Goetz, Stewart, and Charles Taliaferro. A Brief History of the Soul. Wiley-Blackwell, 2011.

Hatfield, Gary. “The Cognitive Faculties”. In The Cambridge History of SeventeenthCentury Philosophy, edited by Daniel Garber and Michael Ayers, pp. 953-1002. Cambridge: Cambridge University Press, 2003.

Hobbes, Thomas. Leviathan, or The Matter, Forme, \& Power of a Common-Wealth Ecclesiasticall and Civill, London: Andrew Crooke, 1651.

Jolley, Nicholas. Locke. His Philosophical Thought, Oxford: Oxford University Press, 1999.

Lähteenmäki, Vili. "Locke and Active Perception”. In Active Perception in the History of Philosophy. From Plato to Modern Philosophy, edited by José Filipe Silva and Mikko Yrjönsuuri, pp. 223-239. Springer, 2014.

Locke, John. An Essay Concerning Human Understanding. Edited by Peter H. Nidditch. Oxford: Clarendon Press, 1975 [1690].

Marshall, John. “Locke, Sociniansim, „socinianism”, and Unitarianism”. In English Philosophy in the Age of Locke, edited by M. A. Stewart, pp. 111-182. Oxford: Clarendon Press, 2000.

More, Henry. The Immortality of The Soul. Edited by A. Jacob. Dordrecht: Martinus Nijhoff, 1987 [1659].

Nuovo, Victor. "Locke's Theology, 1694-1704". In English Philosophy in the Age of Locke, edited by M. A. Stewart, pp. 183-215. Oxford: Clarendon Press, 2000.

Reid, Jasper. "Henry More on Material and Spiritual Extension". Dialogue XLII (2003), pp. 531-558.

Reid, Jasper. The Metaphysics of Henry More. Dordrecht: Springer, 2012.

Scribano, Emanuela. "I sociniani e la metafísica moderna: il caso di Samuel Colliber" [The Socinians and modern metaphysics: the case of Samuel Colliber]. In Filosofia, scienza e politica nel settegento britannico, edited by Luigi Turco, pp. 303-314. Padova: Il Poligrafo, 2003.

Stewart, M. A. "Arguments for the Existence of God: The British Debate". The Cambridge History of Eighteenth-Century Philosophy, edited by Knud Haakonssen, pp. 710-730. Cambridge: Cambridge University Press, 2006. 
Stump, Eleonore. Aquinas. London: Routledge, 2003.

Thiel, Udo. "Personal Identity". In The Cambridge History of Seventeenth-Century Philosophy, edited by Daniel Garber and Michael Ayers, pp. 868-912. Cambridge: Cambridge University Press, 1998.

Thiel, Udo. The Early Modern Subject. Self-Consciousness and Personal Identity from Descartes to Hume. Oxford: Oxford University Press, 2011.

Wainwright, Arthur W. "Introduction". In John Locke, A Paraphrase and Notes on the Epistles of St. Paul, edited by Arthur W. Wainwright. 2 vols. Oxford: Clarendon Press, 1987.

Yolton, John W. Thinking Matter. Materialism in Eighteenth-Century Britain. Oxford: Basil Blackwell, 1983.

Yolton, John W. "Introduction". In Samuel Colliber, Free Thoughts Concerning Souls. In Four Essays. Bristol: Thoemmes, 1990.

Yolton, John W. The Two Intellectual Worlds of John Locke. Man, Person, and Spirits in the Essay. Ithaca: Cornell University Press, 2004.

Yolton, John W. "Colliber, Samuel". In The Continuum Encyclopedia of British Philosophy, edited by A. C. Grayling, Naomi Goulder, and Andrew Pyle, p. 673. Continuum, 2006.

\section{Abstract}

\section{Samuel Colliber on the Soul and Immortality}

This paper presents and discusses Samuel Colliber's theory of the soul in its philosophical and theological setting. His reflections on the soul have not been studied methodically, but, as I hope to show, they deserve more attention for at least two reasons. First, Colliber appropriates a set of terms, concepts and views from Locke's Essay, but he modifies them for the sake of his own scheme in historically interesting ways. He provides a closed list of cognitive acts or operations, claiming that they are all modes of sensation or perception proceeding from a single unitary faculty. He contends that some of these operations depend on the body while others, most notably internal sensation, do not. Second, Colliber applies this account to the post-mortal states of the soul in a systematic manner. He argues for the distinction and separability of soul and body and gives a fairly detailed description of the capabilities and operations of the soul in its separate state. At the same time, he distances himself from the Cartesian view that the soul is an immaterial substance whose essence excludes everything corporeal. He holds that the natures of soul and body are different but not completely disparate.

Key words: Colliber, Locke, soul, immortality 